Sign Systems Studies 30.1, 2002

\title{
Biosemiotic knowledge - a prerequisite for valid explorations of extraterrestrial intelligent life
}

\author{
Elling Ulvestad \\ Department of Microbiology and Immunology, The Gade Institute, \\ Haukeland University Hospital, \\ Armauer Hansen Building, 5021 Bergen, Norway \\ e-mail: elling.ulvestad@ haukeland.no
}

\begin{abstract}
The scientific search for extraterrestrial intelligent life is probably one of the most ambitious projects ever taken in biology. The article discusses methodological problems associated with the search. It is emphasized that investigators of extraterrestrial intelligence, in contrast to investigators of terrestrial matters, have no valid pre-understanding of their subject matter. In this barren setting, utilization of semiotic knowledge is shown to be a prerequisite for achievement of valid data. Owing to methodological shortcomings, it is concluded that the NASA funded project SETI (Search for Extraterrestrial Intelligence) has little if any relevance for the detection of intelligent life in other worlds.
\end{abstract}

It is a capital mistake to theorise before one has data. Insensibly one begins to twist facts to suit theories, instead of theories to suit facts.

Arthur Conan Doyle (1976: 3)

Intelligent life in other worlds has been a major theme of 20th century science and popular culture. For a long time inadequate technology and immense spatiotemporal distances hindered proper scientific investigations of the universe, and human ideas of extraterrestrial intelligent life were based largely on theories abducted from ambiguous and sometimes irreproducible observations (Dick 1996). Much of this changed during the latter half of the 20th century with the 
advent of more sophisticated technology and scientific methodology. A new discipline, astrobiology, evolved to study life's origin, evolution, distribution and interactions. The subject's current scientific credibility is reflected by an increasing number of papers in leading journals and by the recent establishment of two new journals, Astrobiology and International Journal of Astrobiology. In addition, the NASA Astrobiology Institute, a partnership between the National Aeronautics and Space Administration (NASA) and a number of academic research organizations in the USA, was recently established to promote, conduct, and lead integrated multidisciplinary astrobiology research.

Whereas the improbability of extraterrestrial life has been proclaimed by biologists of many stripes, some scientists believe on statistical grounds that life has arisen independently several places in the universe. For example, Robert Bieri (1964: 277), who holds an extreme Panglossian and deterministic view of evolution, believes that extraterrestrial intelligent beings will evolve by necessity and that they "will look an awful lot like us". In contrast, the evolutionary biologist Ernst Mayr (1988: 67-74) holds a probabilistic view and denounces Bieri's idea of a straight line from the origin of life to intelligent man. Mayr pictures evolution as a branching tree full of chance nodes and makes clear how incredibly improbable it is that intelligent life, as we know it, has appeared. Mainstream biology of today endorses the probabilistic view, holding the deterministic view as misguided.

The scientific search for extraterrestrial intelligent life is perhaps the most ambitious initiative ever undertaken in biology. As of today there are no certain observations of life beyond Earth, and some scientists therefore claim that astrobiology in reality is a subject without subject matter. However, encouraging scientific observations, especially concerning probable presence of microbiological life in space (Thomas-Keprta et al. 2001), have motivated further explorations. Ever increasing technological sophistication combined with research funds of astronomical proportions and an almost obsessive wish to learn whether we are alone in the universe or not may well turn astrobiology into the major scientific enterprise of this millennium. 


\section{Appropriating unknown life forms}

Rationality and methodology are intimately connected; to be rational in science is to select good means to pursue scientific goals. Thus, before approaching their subject matter rational scientists set out to validate the methods used for their investigation. This enterprise is made explicit when they design experiments to discriminate among a set of competing hypotheses, during which care is taken to include relevant negative and positive controls that may serve as a frame of reference for the experiment. It is central to experimental methodology that controls and other background knowledge of the subject matter are not independently tested in the experiment. Rather, scientists try to find auxiliary assumptions that they have good reasons to believe are true regardless of what the experimental observations may bring to bear on the hypotheses (Sober 1999).

A challenge for investigators of extraterrestrial intelligent life is that they, in contrast to investigators of terrestrial matters, have little valid pre-understanding of their subject matter. Even though the physical properties of the elements and the laws of physics may be regarded as universal (Wilczek 2002), astrobiologists have no scientifically grounded idea of what physical realizations intelligent life in other worlds may have. Since there is no assurance that life beyond Earth will be Earthlike, terrestrial biological principles and data do not necessarily provide valid information when inferring life in other worlds (Conrad, Nealson 2001). Paradoxically, extrapolation of terrestrial principles to other worlds may preclude any chance of finding new principles of life.

The unavailability of valid background knowledge of extraterrestrial intelligent life makes it irrational to proceed further with a scientific practice that relies explicitly on such knowledge. It is therefore necessary to establish a basis for investigations of extraterrestrial life that does not rely on ontological claims. In an ontologically barren setting it is appropriate to investigate whether founding principles can be grounded in epistemology - whether it is time to invoke and revitalize the Cartesian epistemic cut. When confronting a world full of untruth and scepticism, René Descartes (1968) sought and found in the existential cogito ergo sum a first principle that he could utilize as a basis for his further studies. Although Descartes (1968: 54) believed that "the things we conceive very clearly and very distinctly are all 
true", he also realized that "there is nevertheless some difficulty in being able to recognize for certain which are the things we see distinctly". By the latter qualification he acknowledged uncertainties as regarding the status of auxiliary assumptions.

Unlike Descartes' principle the founding principle in studies of extraterrestrial intelligence can not be grounded in an existential claim. The existence of extraterrestrials is, after all, what astrobiology pursues. It therefore seems reasonable to look for a founding principle in the practice and methods used to appropriate unknown life forms.

It is conceivable that an essential characteristic common to all kinds of intelligent life will be transfer of information through communication. Even though this would appear rational, science has no idea of what kind of communication extraterrestrials engage in. Science should therefore be cautious not to dismiss as ill adapted any of the imaginable physical realisations that extraterrestrial communication channels and sense organs may take. There may be multiple realisations of the same communication channel, as is known from terrestrial biology where eyes have evolved independently at least 40 times during evolution (Mayr 1988). Furthermore, extraterrestrials may have sense organs that are quite unimaginable to humans. Man's limited abductive powers were illustriously revealed during the explication of the lateral lines in fishes: "The fact that man does not have this sense organ himself, and had not perfected artificial receptors in any way analogous, was a handicap in the attempt to understand the organ" (Williams 1966: 11).

The kind of anthropocentrism discussed in the previous paragraph may be a hinder to man's endeavour to obtain a deeper understanding of communicative life. It would thus appear necessary to transgress the constraints imposed by anthropocentrism and substitute it with a broader biocentric perspective. Jakob von Uexküll (1982) made an attempt at this when he used the term umwelt to depict the subjective features of an animal's environment. An animal's umwelt includes all the meaningful aspects of the world it inhabits. Various species of animals, like rat and man, will by consequence have different umwelten. A similar insight was captured in Martin Heidegger's (1962) distinction between two types of being, being-in (with a hyphen) and being in. Whereas the common understanding of being in is of something physically enclosed, being-in is not a physical property but relates to the organisms concerned dealings with its surroundings. 
Heidegger holds that biology, which is concerned with causal explanations, can not study the way life is lived. Life is to be understood as a practical activity and not as a scientific entity or process defined in biochemical terms. A condensed and clear exposition of these thoughts were captured in a famous aphorism by Ludwig Wittgenstein (1953: 223) who stated that if a lion could talk, man would not be able to understand her. The combined insights of Uexküll, Heidegger and Wittgenstein allow us to conclude that two species with homologous sense organs that perceive the same physical stimuli may still inhabit different lifeworlds. The possibility of achieving meaningful communication with extraterrestrial intelligent life having other evolutionary trajectories and umwelten than human beings should therefore, accordingly, be very small.

One can of course argue that terrestrial animals are neither conscious nor intelligent, thereby being irrelevant to discussions of extraterrestrial intelligence. However, this counterargument misses the point since the issue addressed by Uexküll, Heidegger and Wittgenstein is philosophical, not scientific. The issue at stake concerns scientific methodology, not ontology. Whether animals have consciousness or not is therefore only indirectly relevant. Even so, scientific elucidation of animal consciousness may have bearings on the philosophical question. As it is, animal consciousness is a matter about which science is very vague. Donald Griffin, who discovered how bats navigate in the dark using their own sonar, recently stated when discussing animal consciousness: "In the face of very weak evidence we scientists tend to make very strong, negative statements [...] when we really don't know" (Vines 2001: 50). Furthermore, he proclaimed that the key to understand the minds of other animals lies in the communication systems, but that it is "very, very difficult to get convincing evidence" (Vines 2001: 51).

Unprejudiced information about other life forms can only be appropriated by using a scientific method that does not rely on specific physical realisations of that life. I believe that this methodological demand can be met by combining sound biological principles with semiotics. Tønnessen (2001: 689), although sceptical to speculations about what may constitute universal characteristics of living beings, likewise argues that "one should presume that semiosis is a universal characteristic of living beings, because without semiosis, there can be no recognition". A main advantage when utilising 
biosemiotics to study communication is that semiotics, although relying on the physical attributes of objects, is not dependent upon their specific physical realization. According to Peirce (1998) semiotic communication involves the sign, the object that the sign refers to, and the interpretant. For something to be a sign it must be understood as such - a sign is a sign only in context. Signs must be interpreted in relation to each other in a context, otherwise they may not even be acknowledged as signs. It is a fundamental principle in Peirce's semiotics that indexical and iconic signs, and especially symbolic signs, have no meaning in isolation. The puzzles connected with background knowledge are therefore explicitly taken care of and acknowledged by biosemiotics.

\section{SETI - a misguided scientific approach}

Communication with extraterrestrial intelligence poses semiotic problems of both philosophical and physical character. If the semiotic problems are not explicated and solved at the philosophical level, solving the technological problems may be a futile endeavour having no bearings on the problem at hand. Such reasoning sets the background for my own scepticism towards the evidential bearings of one of the most ambitious astrobiological projects ever, the NASA funded project SETI (Search for Extraterrestrial Intelligence). SETI has consumed enormous amounts of resources in an attempt to get in contact with extraterrestrials. Since the early 1960s SETI has dealt with the communicative problem in two ways. First by sending a message into deep space that would allow any intelligent extraterrestrial to figure out that it was produced by intelligent designers, and second by scanning the night sky for narrow-band radio emissions hoping to detect signs of intelligent life elsewhere in the universe. SETI concentrated on listening for electromagnetic signals in the centimetre waveband, the reason being purely practical since that is where the background noise from the universe and the Earth's atmosphere is lowest (Dick 1996).

The SETI engineers search for radio emissions, not because this is an a priori sign of intelligence, but because they know the sorts of mechanisms that are needed to produce radio waves. It thus appears 
that fundamental semiotical problems are relayed to the background because of the practical convenience of radio waves. The earthcentric presumptions of the SETI project was explicitly articulated when the journal Nature on October 21, 1993 on the front page asked "Is there life on Earth?", a question that was answered in the affirmative by Carl Sagan et al. (1993) in the same issue. Carl Sagan and the other scientists reported results obtained from experiments performed in December 1990 when the Galileo spacecraft flew within $960 \mathrm{~km}$ of Earth. As Galileo passed by the Earth it made a series of observations to test its onboard instruments. It detected abundant oxygen in the Earth's atmosphere. In addition, narrow-band radio transmissions from Earth were detected. Taken together, this evidence implied that not just life, but intelligent life existed on Earth. Although the experiments were technically successful, it is arguable whether the experiments have any relevance for the detection of intelligent life in other worlds. Rather, it can be argued that the only conclusion that can be drawn from the experiment is that creatures on Earth send radio signals that can be received in space. That the same creatures are intelligent can not be inferred from the experimental data without a concomitant background knowledge that explains how narrow-band radio transmissions are generated and by whom.

The biological rationale for the SETI project can be found in certain assumptions derived from an interpretation of evolutionary theory explicated and defended most vehemently by Richard Dawkins (1983: 35). He claims that "The Darwinian law [...] may be as universal as the great laws of physics", and holds that complex structures found anywhere in the universe are/were either alive or are/were artefacts created by something that is/was alive. According to this theoretical framework one can envision extraterrestrial radio signals as artefacts generated by humanoids on other planets $\left(H_{1}\right)$. Although evolutionary theory is opposed to the design argument for explaining biological diversity, the theory is not opposed to deployment of the design argument for explaining artefacts. As such, the design argument is valid for scientific inference. Radio signals could therefore be looked upon as valuable signs of meaning in the universe. However, when regarded as a scientific hypothesis, I hold that we have little reason to believe $H_{1}$ rather than the opposite hypothesis - that the signals are not generated by humanoids on other planets $\left(H_{2}\right)$. Since there are no valid data to support the hypotheses, both hypotheses 
have identical likelihoods, $p\left(\right.$ signal $\left.\mid H_{1}\right)=p\left(\right.$ signal $\left.\mid H_{2}\right)$. It is only earthcentric background knowledge that inclines us to believe that the likelihood of $H_{1}$ is higher than $H_{2}$.

Although not explicitly acknowledged, the SETI project appears to be based on the abandoned deterministic model of evolution, not the endorsed probabilistic model. For example, SETI implicitly expects that humanoids are equipped with receivers among their sense organs that respond to the same auditory signals that humans do. Furthermore, since the reception of any message is dependent on prior knowledge of the possibilities, it is expected that humanoids have a similar evolutionary history to the one that occurred on Earth. I find both assumptions incomprehensible, and consequently find the utilization of radio waves as means for contact with extraterrestrial intelligence dubious also from an evolutionary angle.

\section{Concluding remarks}

At face value the SETI project, by focusing on signs of meaning in the universe, may be regarded as a project testing the hypothesis of universal Darwinian evolution (Dawkins 1983). The investigations may also seem to have bearings on the biosemioticians' claim that life is based entirely on semiosis, on sign operations (Hoffmeyer 1996; Emmeche 1998). Finally, the SETI project may be looked upon as a test for the claim of universal biosemiotics. However, given the philosophical and semiotic criticisms raised against the SETI project I find it rather unlikely that the results of the project will have any bearings on the issues raised. The several unjustified background assumptions of the SETI project need to be thoroughly discussed and revised before any scientific meaning can be bestowed to data. These discussions should be conducted on a biosemiotic footing.

\section{References}

Bieri, Robert 1964. Humanoids on other planets? American Scientist 52: 452-458. Conrad, Pamela G.; Nealson, Kenneth H. 2001. A non-earthcentric approach to life detection. Astrobiology 1: 15-24. 
Dawkins, Richard 1998 [1983]. Universal Darwinism. In: Hull, David L.; Ruse, Michael (eds.), The Philosophy of Biology. Oxford: Oxford University Press, $15-37$.

Descartes, René 1968. Discourse on Method and the Meditations. London: Penguin Books.

Dick, Steven 1996. The Biological Universe: The Twentieth-Century Extraterrestrial Life Debate and the Limits of Science. Cambridge: Cambridge University Press.

Doyle, Arthur Conan 1976. A scandal in Bohemia. In: The Illustrated Sherlock Holmes Treasury. New York: Avenel Books.

Emmeche, Claus 1998. Defining life as a semiotic phenomenon. Cybernetics and Human Knowing 5: 3-17.

Heidegger, Martin 1962. Being and Time. Oxford: Blackwell Publishers Ltd.

Hoffmeyer, Jesper 1996. Signs of Meaning in the Universe. Bloomington: Indiana University Press.

Mayr, Ernst 1988. Toward a New Philosophy of Biology: Observations of an Evolutionist. Cambridge: The Belknap Press of Harvard University Press.

Peirce, Charles Sanders 1998. Pragmatism. In: The Peirce edition project (ed.), The Essential Peirce: Selected Philosophical Writings, volume 2 (1893-1913). Bloomington: Indiana University Press, 398-433.

Thomas-Keprta, Kathie L; Clemett, Simon J.; Bazylinski, Dennis A.; Kirschvink, Joseph L.; McKay, David S.; Wentworth, Ssusan J.; Vali, Hojatollah; Gibson, Everett K. Jr.; McKay, Mary F.; Romanek, Christopher S. 2001. Truncated hexa-octahedral magnetite crystals in ALH84001: presumptive biosignatures. Proc Natl Acad Sci USA 98: 2164-2169.

Tønnessen, Morten 2001. Outline of an Uexküllian bio-onotology. Sign Systems Studies 29(2): 683-691.

Sagan, Carl; Thompson, W. Reid; Carlson, Robert; Gurnett, Donald; Hord, Charles 1993. A search for life on earth from the Galileo spacecraft. Nature 365: 715-721.

Sober, Elliott 1999. Testability. Proceedings and Addresses of the American Philosophical Association 73: 47-76.

Uexküll, Jakob von 1982. The theory of meaning. Semiotica 42(1): 25-82.

Vines, Gail 2001. Something like us. New Scientist 30 June, 49-51.

Wilczek, Frank 2002. Setting standards. Nature 415: 265.

Williams, George C. 1966. Adaptation and Natural Selection. Princeton: Princeton University Press.

Wittgenstein, Ludwig 1953. Philosophical Investigations. Oxford: Blackwell Publishers. 


\section{Необходимость биосемиотического знания при поисках внеземного разума}

Научный поиск внеземного разума один из самых амбициозных проектов, когда-либо предпринятых в биологии. Данная статья рассматривает связанные с этим проектом методологические проблемы. Подчеркивается, что искатели внеземного разума не обладают, в отличие от исследователей земных материй, нужным предварительным знанием об объекте своего исследования. В качестве предпосылки получения заслуживающего доверия результатов автор видит использование семиотической методологии. Делается вывод, что финансируемый НАСА проект СЕТИ (Поиск внеземного разума) не может из-за своих методологических недостатков иметь успех при поиске внеземного разума.

\section{Biosemiootilise teadmise tarvilikkus maavälise mõistusliku elu usaldusväärseil otsinguil}

Maavälise elu teaduslik otsimine on tõenäoliselt üks ambitsioonikamaid projekte, mis bioloogias kunagi ette võetud. Siinne artikkel arutleb otsingutega seotud metodoloogiliste probleemide üle. Rõhutatakse, et maavälise mõistuslikkuse otsijad ei oma, erinevalt maiste asjade uurijatest, arvestatavat eelteadmist oma uurimisobjektist. Selle piirava teguri tõttu nähakse semiootilise metodoloogia kasutuselevõttu kui eeldust usaldusväärsete tulemuste saamiseks. Järeldatakse, et NASA poolt finantseeritud projekt SETI (Maavälise mõistuslikkuse otsing) ei saa tänu metodoloogilistele puudujääkidele olla maavälise mõistusliku elu otsimisel kuigi edukas. 